\title{
Determination of Glycoconjugate Residues of Erythrocytes at Different Age Groups of Rats
}

\author{
Ayca GUMUS, Erdal BALCAN \\ Celal Bayar University, Faculty of Science and Literature, Department of Biology, Manisa, TURKEY
}

\begin{abstract}
Aging is a time-dependent process that contains cell injury caused by molecular damages and eventually functional impairment of tissues and organs. The possible roles of cell surface carbohydrates, which are very important molecules in cell to cell and/or cell to extracellular matrix recognition, on aging process are not yet clear. In this study, glycoconjugate alterations of membrane glycoproteins of erythrocytes in aging organism were evaluated with lectin histochemistry and lectin blotting studies in 1, 4 and 7 months old rats. Lectin histochemistry results indicated that $\alpha(2 \rightarrow 3)$ and $\alpha(2 \rightarrow 6)$-linked sialic acids are intensively found in erythrocyte membranes, but this intensity of sialic acids decreases with age. Similar evidences were obtained from lectin blotting studies which performed with same lectins. These results suggest that sialic acid reactivity alters with the age of organism. We thought that (a) sialic acid containing glycoconjugates altered not only with erythrocyte senescence, but also aging process of organism or (b) the number of sialic acid containing erythrocytes decreased by age.
\end{abstract}

Keywords: Erythrocyte, Glycoconjugates, Lectin, SDS-PAGE, Sialic acid, Aging

\section{ÖZET}

\section{Farklı Yaş gruplarına Ait Rat Eritrositlerinin Glukokonjugat İçeriklerinin Belirlenmesi}

Yaşlanma, moleküler bozulmaların neden olduğu hücre hasarını ve bunu takiben doku ve organların fonksiyonel olarak zayıflamasını içeren, zamana bağlı bir süreçtir. Hücre-hücre ve/veya hücre-ekstrasellüler matriks arasındaki tanıma olaylarında önemli moleküller olan hücre yüzey karbohidratlarının yaşlanma sürecindeki olası rolleri hakkında yeterli bilgi bulunmamaktadır. Bu çalışmada, eritrositlerde membran glikoproteinlerine ait glukokonjugatların organizma yaşlanması sürecindeki değişiklikleri 1, 4 ve 7 aylık ratlarda lektin histokimyası ve lektin blotting yöntemleri kullanılarak belirlenmeye çalışıldı. Lektin histokimyası sonuçları, $\alpha(2 \rightarrow 3)$ ve $\alpha(2 \rightarrow 6)$ bağlı sialik asitlerin eritrosit membranlarında yoğun olduğunu, ancak bu yoğunluğun yaş ile birlikte belirgin bir azalmaya gittiğini göstermiştir. Aynı lektinler kullanarak yapılan blotting çalıșmalarında benzer bulgular elde edilmiştir. Bu sonuçlar, sialik asit reaktivitesinin organizmanın yaşlanmasına bağımlı olarak azaldığını göstermektedir. Bu durum, (a) sialik içeren glukokonjugatların sadece eritrosit yaşlanması ile değil aynı zamanda organizmanın yaşlanması sürecinde de değişim gösterdiğini ya da (b) sialik asit içeren eritrosit sayısının yaşlanma ile azaldığını düşündürmüştür.

Anahtar Kelimeler: Eritrosit, Glukokonjugatlar, Lektin, SDS-PAGE, Sialik asit, Yaşlanma 


\section{INTRODUCTION}

Glycan moieties of glycoconjugates, known as fundamental energy sources and building blocks of complex biological systems, are compose integral parts of many plasma and secretory proteins. ${ }^{12}$ They are found in cell surfaces ${ }^{3-7}$, cytoplasm or organelles as well as intercellular areas or fluids ${ }^{8}$ and play crucial roles in recognition phenomena.

Sialic acids are the most important terminal sugars that play a crucial role in the achieving functional properties of carbohydrates. They belong to a diverse family of closely related nine-carbon sugars that contain 40 members and derivated from $\mathrm{N}$ acetylneuraminic acids, $\mathrm{N}$-glycolylneuraminic acids and deaminoneuraminic acids. ${ }^{9}{ }^{10}$ Sialic acids can be found in many glycan types such as glycoproteins, glycolipids, glycosaminoglycans and proteoglycans ${ }^{11}$ and play a critical roles in the regulation of cell-to-cell and/or cell-extracellular matrix interactions due to their negatively charges at physiological $\mathrm{pH}^{8,9,12-14}$ They have dual function in recognition phenomena: they can either serve as antigenic determinants in protein-protein interactions or mask the recognition sites and therefore inhibit receptor-ligand interactions. ${ }^{15}$ Sialic acids in erythrocyte membranes play important roles in maintaining the cell integrity and survival as well as keeping the erythrocytes in circulation. ${ }^{16-19}$ It is suggested that amount of sialic acids in erythrocyte membranes diminished by erythrocyte senescen$\mathrm{ce}^{20}$, probably in consequence of alteration of cell surface glycoproteins during the cell aging. ${ }^{21,22} \mathrm{Ne}-$ vertheless, the possible glycoconjugate alterations of erythrocytes obtained from aging organisms remain be unsolved.

The aim of this study was to evaluate the alterations in glycoconjugate patterns of erythrocytes from 1,4 and 7 month old rats by lectin histochemistry and lectin blotting studies.

\section{MATERIAL AND METHODS}

\section{Preparation of Erythrocytes and Membranes}

One ( $n=16)$, four $(n=12)$ and seven $(n=12)$ months old rats were used respectively with permission of Celal Bayar University Medical Faculty Animal Research Ethic Council (Protocol no: 2007/0025). Blood samples were obtained by intracardiac puncture and collected to EDTA containing tubes. After the centrifugation at $3000 \mathrm{rpm}$ for $5 \mathrm{~min}$ at $+4^{\circ} \mathrm{C}$, supernatant and buffy coat were removed by aspiration and erythrocyte washing solution was added to pellet. These steps were repeated three times at same conditions. The washed and separated erythrocyte mass divided in two fragments. One portion diluted with isotonic $\mathrm{NaCl}$ at 1:3 ratio, smeared to slides and fixed with methanol for the lectin histochemistry. Other fraction of erythrocyte mass was lysed by addition of ice-cold membrane preparation reagent in a ratio $1: 20,(\mathrm{vol} / \mathrm{vol})(5 \mathrm{mM}$ Tris- $\mathrm{HCl}$, $0.1 \mathrm{mM}$ EDTA, $\mathrm{pH}$ 7.4). In order to isolation of erythrocyte membranes, lysates were centrifuged at $15000 \mathrm{rpm}$ for $20 \mathrm{~min}$ at $+4^{\circ} \mathrm{C}$, supernatant was removed, and instead membrane preparation reagent was added. These steps were repeated a few times until the erythrocyte membranes extracted..$^{23}$ Thereafter, extracted membranes scaled and stored at $-86^{\circ} \mathrm{C}$ until the employ for sodium dodecyl sulfatepolyacrylamide gel electrophoresis (SDS-PAGE).

\section{Lectin Histochemistry}

In order to identify the glycoconjugates within the erythrocytes, a panel of digoxigenin (DIG) labelled lectins, a series of plant derived non-immune proteins possessing binding sites for different types of mostly specific terminal carbohydrate residues of mammalian cells, (DIG Glycan Differentiation Kit, Cat\# 11210238001) was used (Table 1). Briefly, slides were blocked with $10 \%$ (w/v) blocking buffer (Roche Applied Science) in Tris-buffered saline

Table 1. Data concerning the lectins used in this study

\begin{tabular}{|lll|}
\hline Lectins & Binding specificity & Reference \\
\hline Maackia amurensis agglutinin Lectin (MAA) & NeuNAc $(2 \rightarrow 3 \mathrm{Gal}$ & 24 \\
Sambucus nigra agglutinin Lectin (SNA) & NeuNAc $\alpha(2 \rightarrow 6) \mathrm{Gal}$ & 25 \\
Peanut agglutinin Lectin (PNA) & Gal $\beta(1 \rightarrow 3)$ GalNAc & 26 \\
\hline NeuNAC= N-acetylneuraminic acid; Gal= galactose; GalNAc= N-acetylgalactosamine & \\
\hline
\end{tabular}


(TBS)/ $0.5 \%$ Tween $20, \mathrm{pH} 7.5$ for 30 min and washed 2 times with TBS ( $\mathrm{pH} 7.5$ ) and 1 times buffer 1 [TBS, $1 \mathrm{mM} \mathrm{MgCl} 2$ (Fluka), $1 \mathrm{mM} \mathrm{MnCl} 2$ (Sigma), $1 \mathrm{mM} \mathrm{CaCl}_{2}$ (Sigma), $\mathrm{pH} 7.5$ ] for 10 min each step. Afterwards, slides were washed with TBS and incubated with buffer-1 diluted DIG labelled Maackia amurensis agglutinin (MAA, $10 \mu \mathrm{g} / \mathrm{ml}$ ), Sambucus nigra agglutinin (SNA, $20 \mu \mathrm{g} / \mathrm{ml}$ ) and peanut agglutinin (PNA, $10 \mu \mathrm{g} / \mathrm{ml}$ ) lectins (DIG Glycan Differentiation Kit, Cat\# 11210238001, Roche Applied Science) in a humidified chamber for $1 \mathrm{~h}$, washed two times with TBS and incubated with 1 $\mu \mathrm{l} / \mathrm{ml}$ anti-DIG-alkaline phosphatase (AP) (Roche Applied Science) for $1 \mathrm{~h}$. After washing with TBS, sections were incubated with $20 \mu \mathrm{l} / \mathrm{ml}$ nitro-bluetetrazolium chloride/5-bromo-4-chloro-3-indolyl phosphate (NBT/BCIP) staining reagent (Roche Applied Science) in buffer 2 (0.1 M Tris-HCl, 0.05 $\mathrm{M} \mathrm{MgCl}_{2}, 0.1 \mathrm{M} \mathrm{NaCl}, \mathrm{pH}$ 9.5) for 3-5 min. Reaction was stopped with ultra pure distilled water when dark-brown staining appeared. All the steps above were performed at room temperature.

\section{Control of Lectin Histochemistry}

MAA lectin and a control glycoprotein, fetuin (Roche Applied Science), were mixed in a ratio of 1:2.5 (10 $\mu \mathrm{g} / \mathrm{ml}$ MAA: $25 \mu \mathrm{g} / \mathrm{ml}$ fetuin). In order to confirm of accuracy of the method, some slides were incubated with MAA-fetuin mix prior to lectin histochemistry.

\section{Sodium Dodecyl Sulfate-Polyacrylamide Gel Electrophoresis (SDS-PAGE)}

SDS-PAGE was performed on a $4 \%$ stacking gel and a $7.5 \%$ separating gel according to the discontinuous system of Laemmli. ${ }^{27}$ Gels were stained with 25\% Coomassie Brillant Blue (CBB, Sigma).

\section{Lectin Blotting}

After the SDS-PAGE, gels were sandwiched with wetted $0.2 \mu \mathrm{m}$ pore size polyvinylidene difluoride (PVDF) membranes (ImmunBlot ${ }^{\circledR}$, Bio-Rad) supported by filter papers and pads on each side. Blotting was carried out at $100 \mathrm{~V}, 350 \mathrm{~mA}$ for $2 \mathrm{~h}$ with a Mini Trans-Blot Electrophoretic Transfer Cell (Bio-Rad) according the standard procedure ${ }^{28} \mathrm{Blot}-$ ted membranes were stained with $0.1 \%$ Ponceau $S$ (Sigma). In order to determine cell surface glycoconjugates in erythrocyte of rats at different age groups, PVDF membranes were incubated with three different DIG labelled plant lectins, MAA, SNA and PNA, (DIG Glycan Differentiation Kit, Cat\#11210238001, Roche Applied Science), according to the manufacturer's instructions, as in lectin histochemistry (Table 1). Briefly, PVDF membranes were blocked with $10 \%$ (w/v) blocking buffer (Roche Applied Science) in TBS/0.5\% Tween 20, $\mathrm{pH} 7.5$ for $30 \mathrm{~min}$ at room temperature and washed with TBS (pH 7.5) and buffer 1 for 10 min each step. MAA, SNA and PNA lectins were diluted with buffer 1 in a ratio of 1:200, 1:1000 and 1:100, respectively. Thereafter, PVDF membranes were incubated with pre-diluted lectins for $1 \mathrm{~h}$ at room temperature, washed three times with TBS for 10 min each step, and incubated with $1 \mu \mathrm{l} / \mathrm{ml}$ anti-digoxigenin-AP, in TBS for $1 \mathrm{~h}$. After washing with TBS, in order to determine bound lectins, PVDF membranes were stained with $20 \mu \mathrm{l} / \mathrm{ml}$ NBT/BCIP reagent (Roche Applied Science) in buffer 2 until the bands become visible, and reaction was halted with ultra pure distilled water.

\section{Controls of Lectin Blotting}

Two different negative controls were accomplished. First, erythrocyte membrane proteins obtained from 1 month old rats were incubated with $1 \mathrm{U} / \mathrm{ml}$ of Type X Clostridium perfiringens neuraminidase (Sigma), which hydrolyses $\alpha(2 \rightarrow 3), \alpha(2 \rightarrow 6)$ and $\alpha(2 \rightarrow 8)$ glycosidic linkages of terminal sialic acids, at $38^{\circ} \mathrm{C}$ for $45 \mathrm{~min}$. Enzyme treated protein and a control glycoprotein, fetuin, were subjected SDS-PAGE and transferred to PVDF membranes. Thereafter, samples were incubated with MAA as described above. Second, blotted rat erythrocyte membrane proteins incubated with MAA, SNA and PNA lectins which are pre-diluted with control glycoproteins (for the dilutions, $25 \mu \mathrm{g} / \mathrm{ml}$ fetuin, 50 $\mu \mathrm{g} / \mathrm{ml}$ asialofetuin and $5 \mu \mathrm{g} / \mathrm{ml}$ transferring were used respectively).

\section{RESULTS}

\section{Lectin Histochemistry}

Lectin histochemistry is a morphological technique that takes advantage of the carbohydrate binding characteristics of proteins. Figure 1 summarizes the staining patterns observed in the erythrocytes at all age groups analyzed incubated with DIG labelled lectins. 

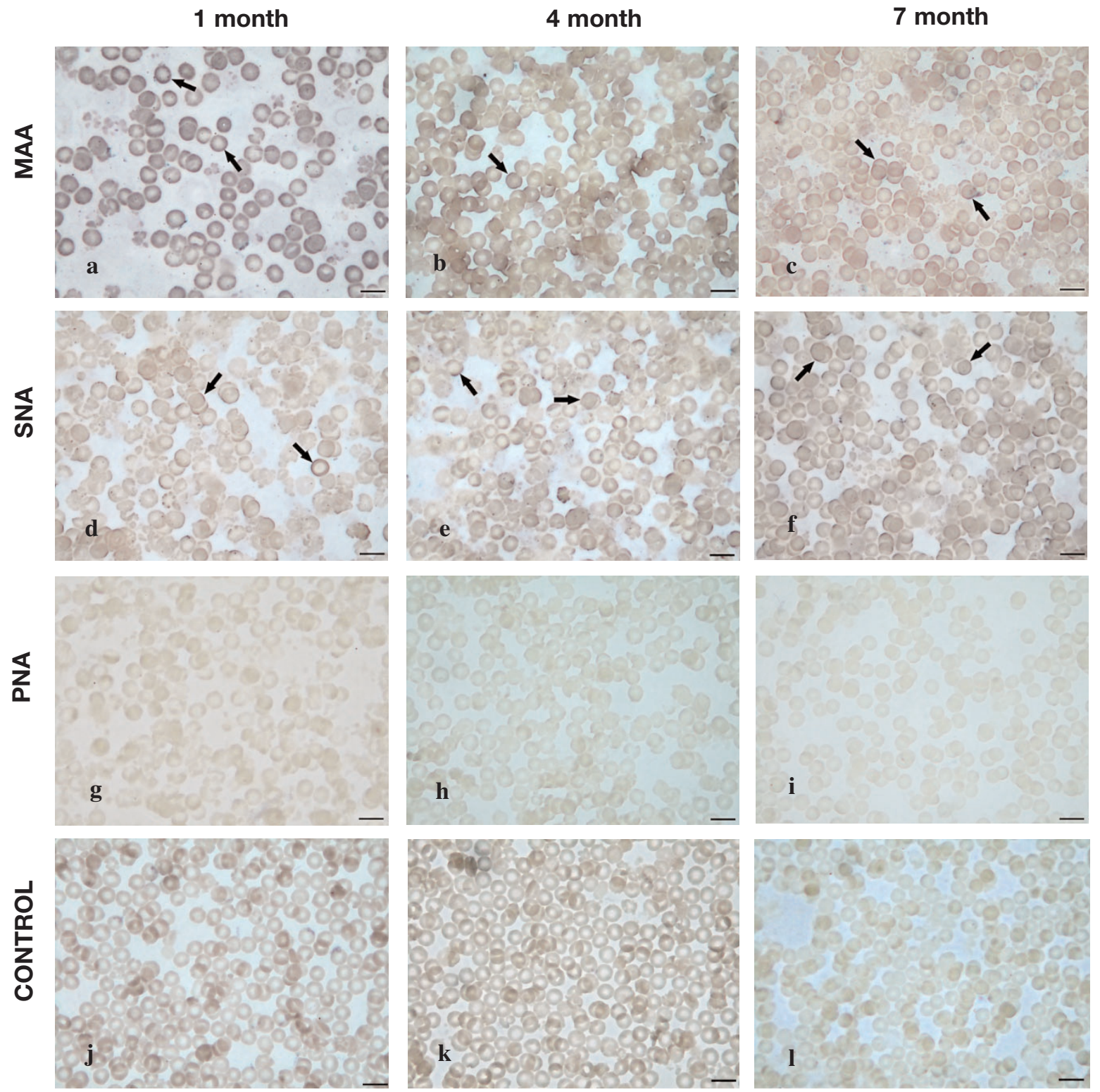

Figure 1. Lectin activities and MAA controls of erythrocyte smears at different age groups Arrows indicate cells recognized by lectins. Bars: $20 \mu \mathrm{m}$

Lectin histochemistry results of MAA, which specific for sialic acid $\alpha(2 \rightarrow 3)$ galactose structures, indicated that erythrocytes from the all evaluated age groups were stained. This positive reaction was more intense in 1-month-old rats (Figure 1a) when compared to 4 and 7-month-old ones (Figure $1 \mathrm{~b}$, c). SNA lectin is specific for sialic acid $\alpha(2 \rightarrow 6)$ galactose linkages. Similar to MAA, positive SNA stainings were observed nearly all the erythrocytes at all age groups and binding intensity of this lectin was stronger in 1-month-old group than others (Figure $1 \mathrm{~d}-\mathrm{f}$ ). However, reactivity of PNA lectin, specific for the $\operatorname{Gal} \beta(1 \rightarrow 3)$ GalNAc disaccharide, was decreased in all groups (Figure $1 \mathrm{~g}$-i).

\section{Control of Lectin Histochemistry}

MAA reactivity was disappeared when the lectin incubated with fetuin prior to lectin histochemistry

\section{Lectin Blotting}

Glycoconjugate changes of erythrocyte membranes belonging to the different age groups were evaluated by lectin blotting technique. The majority of 


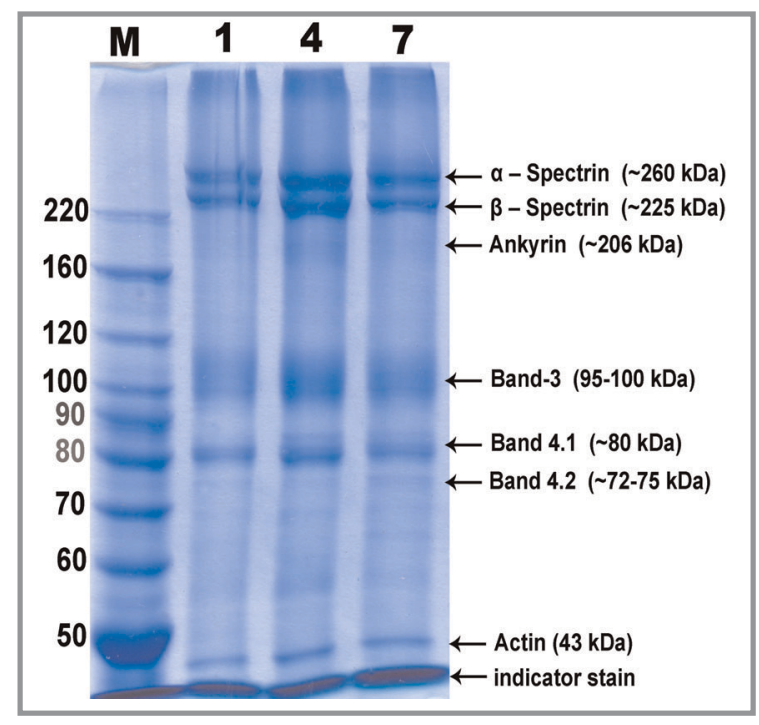

Figure 2. SDS-PAGE analysis of total protein extracts of rat erythrocyte membranes belonging to different age groups. M, marker; 1, 4 and 7 indicate 1 month; 4 month; 7 month old rat erythrocyte membranes, respectively (stained with $\mathrm{CBB}$ ). A set of broad range molecular mass protein standard (Benchmark Broad Range Protein Marker, Invitrogen Cat\#10747012) indicated on the left (M).

proteins detected by coomassie blue staining were not labelled by the lectins (Figure 2).

MAA: Blots of erythrocyte membranes revealed approximately 5 different MAA-reactive bands. While the $90 \mathrm{kDa}$ band (band-3) strongly stained with MAA lectin in 1-month-old rats, staining intensity was decreased in 4- and 7-month-old groups. Other protein bands were weak-positive for MAA in 1 month old erythrocytes and their affinity were also reduced in 4- and 7-month old rats.

SNA: Lectin blotting study with SNA was shown that at least 5 different protein bands with molecular mass ranging from 50 to $220 \mathrm{kDa}$ and one protein of $M r$ upon $220 \mathrm{kDa}$ were reactive in all age groups. However, binding capacities of band-3 and other proteins to SNA were decreased throughout the age (Figure 3a). These results and the lectin histochemistry investigations indicated that $\alpha(2 \rightarrow 3)$ and $\alpha(2 \rightarrow 6)$ linked sialic acids were decreased during the aging.

PNA: With the PNA lectin blotting, three protein bands with molecular weight upon $100 \mathrm{kDa}$ were weakly stained in all age groups (Figure 3c), so that these proteins might contain galactose residues which are come in slight following by the sialic acid degradation.

\section{Control of Lectin Blotting}

For the check of lectin blotting technique, pure fetuin and Type X C. Perfiringens neuraminidase treated erythrocyte membrane proteins obtained from 1-month-old rats were separately blotted with MAA. Strong affinity of MAA to fetuin (Figure 4a) was disappeared when erythrocyte membranes were treated with enzyme (Figure 4b). Secondly, lectins, which are pre-incubated with control glycoproteins (fetuin for MAA, transferrin for SNA and asialofetuin for PNA) were incubated with erythrocyte membrane proteins and a decreased lectin activity was observed (Figure $5 \mathrm{a}, \mathrm{b}, \mathrm{c}$ ).

\section{DISCUSSION}

Due to their pivotal roles in cell-cell and/or cellextracellular matrix interactions, cell surface glycan molecules were became an important target in cell biology. ${ }^{1,2,89}$ Previous studies indicated that erythrocyte membrane proteins (and lipids) are glycosylated forms and glycosylation status of these molecules is closely related with functions of erythrocytes. ${ }^{16-19}$ A considerable amount of work has been elucidate the diminution of erythrocyte membrane sialic acids during the erythrocyte senescence. ${ }^{21,29}$ However, data on the alterations of glycosylation status in erythrocyte membranes during the organism's ageing is absent. Our lectin histochemistry results shown that MAA and SNA lectins, which are specific for $\alpha(2 \rightarrow 3)$ and $\alpha(2 \rightarrow 6)$ linked sialic acids respectively, recognize some erythrocytes, but not all. This situation can be interpreted as meaning that MAA- and SNA-reactive erythrocytes are younger than non-reactive ones.

In agreement with previous studie ${ }^{30-33}$, our data provide direct evidence that MAA- and SNA-reactive erythrocytes bear O-linked and hybrid or complex $N$-linked glycosylated molecules in their membranes. Meanwhile, decreased MAA and SNA reactivity in erythrocytes from 4- and 7-month-old rats thought that sialylation pattern of erythrocytes belonging to older rats is diminished. Lectin blotting studies were confirmed the lectin histoche- 


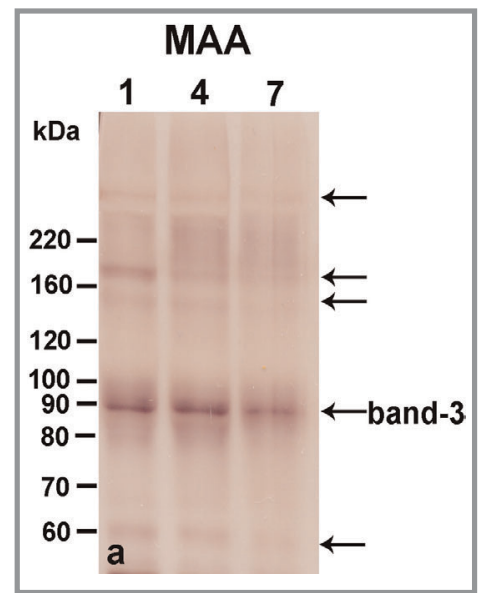

Figure 3a. MAA lectin blotting analysis of total protein extracts of rat erythrocyte membranes from different age groups.

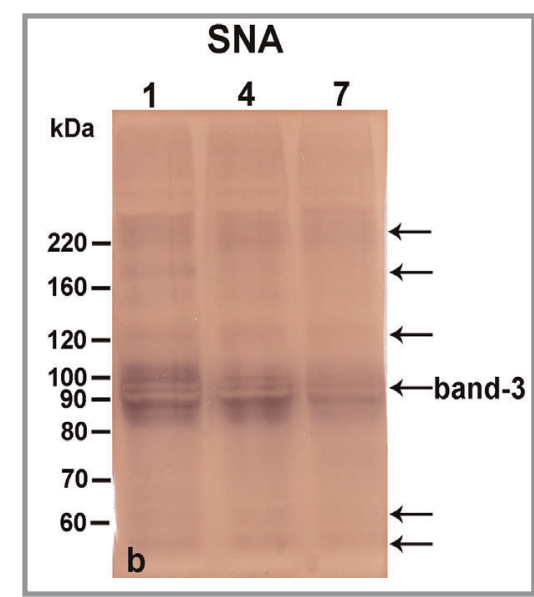

Figure 3b. SNA lectin blotting analysis of total protein extracts of rat erythrocyte membranes from different age groups.

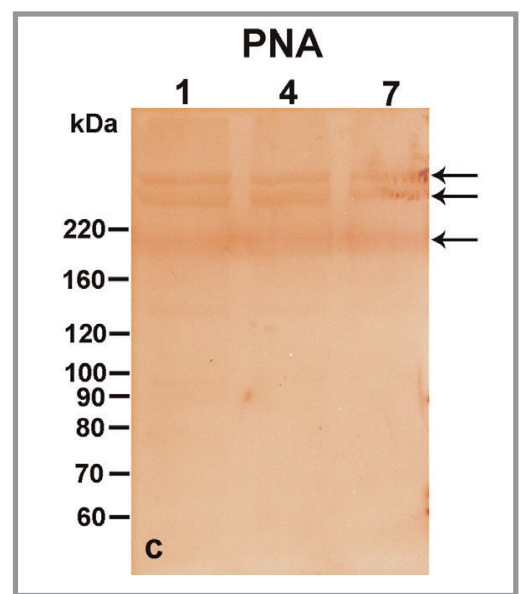

Figure 3c. PNA lectin blotting analysis of total protein extracts of rat erythrocyte membranes from different age groups. M, marker; 1, 4 and 7 indicate 1 month; 4 month; 7-month-old rat erythrocyte membranes, respectively. mistry. Similar to histochemical analyses, affinity of protein bands to lectins was diminished at 4 and 7 months. Bratosin and her colleagues ${ }^{34}$ have suggested that binding affinity of SNA, Wheat germ agglutinin and Limulus polyhemus agglutinin in young erythrocytes is more than senescent ones. Similarly, Seaman and co-workers ${ }^{35}$ have proposed that reduction of sialic acids is result from erythrocyte membrane loss. While these works suggest the sialylation of erythrocyte membranes decreased by the erythrocyte aging, reason(s) of this diminution is poorly understood. Three possible situations can be supposed: First, diminution of glycoprotein content in erythrocyte membranes, secondly, loss of erythrocyte membranes and finally, loss of oligosaccharide moieties in erythrocyte membrane proteins. These situations can be valid for our results. In conclusion, it can be said that, amount of sialic acid is decreased in aging erythrocytes and also in erythrocytes from aging organisms. On the other hand, alteration in the glycophorin $\mathrm{A}$, an integral membrane glycoprotein which consists of large numbers of sialic acid molecules, is responsible for the diminished levels of sialic acids in ageing erythrocytes ${ }^{36}$ Our lectin blotting studies with MAA and SNA showed that band-3 is also an important factor for sialic acid diminution. Contrary to previous studies $^{34,37}$, our lectin histochemistry studies indicated that PNA lectin slightly recognize erythrocytes at all the stages. In addition to this, PNA-positive protein bands were also recognized by MAA and SNA in lectin blotting studies. In this instance, it can be conceive that $\alpha(2 \rightarrow 3)$ and $\alpha(2 \rightarrow 6)$ linked sialic acids mask the PNA binding regions of membrane glycoproteins in young rats and during the aging, sialic acid amount is decreased, therefore PNA-reactive structures appeared in erythrocyte membrane glycoproteins of old animals.

Band-3 is an erythrocyte membrane glycoprotein of molecular weight approximately $100 \mathrm{kDa} .{ }^{38}$ Its carbohydrate content separates two fractions: high molecular weight and low molecular weight oligosaccharides..$^{39}$ Peripheral sides of high molecular weight oligosaccharides carry polylactosaminyl side chains consisting of various numbers of a repeating disaccharide $\alpha(1 \rightarrow 4)$ GlcNAc $\alpha(1 \rightarrow 3)$. Low molecular weight fraction contains complex type oligosaccharides such as galactose, mannose, fucose and $\mathrm{N}$-acetylglycosamine (GlcNAc).$^{40}$ Sialic acid groups of band-3 are located in terminal region of polylactosaminyl side chains ${ }^{41}$ In agreement with the previous suggestions ${ }^{42}$, our MAA and SNA lectin blotting studies indicated that $100 \mathrm{kDa}$ band (band-3) proteins contain both $\alpha(2 \rightarrow 3)$ and $\alpha(2 \rightarrow 6)$ linked sialic acids.

In conclusion, while the erythrocyte membrane glycoconjugates alterations during the erythrocyte senescence well known ${ }^{20}$, the identify of lectin bin- 


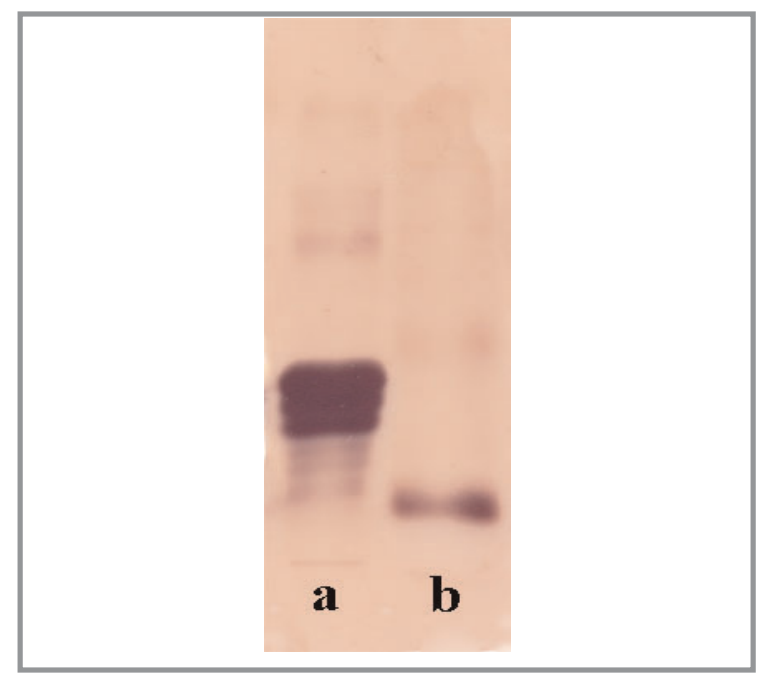

Figure 4. Control of lectin blotting. MAA strongly reacted with fetuin (lane $\mathbf{a}$ ), whereas Type $X$ neuraminidase treated erythrocyte membrane extracts from 1 month old rats did not react (lane b).

ding pattern of erythrocytes in aging organism remains to be established. We examined this question in the present study in order to whether the relationship between erythrocyte membrane glycoconjugate alterations and organism's aging. Our results indicated that some alterations occur in erythrocyte membrane glycoconjugates during oganism's aging process, probably according to well orchestrated alterations of aging. Therefore, detailed investigation of alterations in cell surface glycoconjugates during the aging process will facilitate to understand this complex course.

\section{ACKNOWLEDGEMENTS}

This study is financed by Celal Bayar University Scientific Research Projects Committee (Project no: FEF-2007-056) and supported by Celal Bayar University Medical Faculty Animal Research Ethic Council (Protocol no: 2007/0025).

\section{REFERENCES}

1. Stoolman LM. Adhesion molecules controlling lymphocyte migration. Cell 56: 907-910, 1989.

2. Lis H, Sharon N. Lectins: Carbohydrate-Specific Proteins That Mediate Cellular Recognition. Chem Rev 98: 637-674, 1998.

3. Furukawa K, Kobata A. Protein glycosylation. Curr Opin Biotechnol 3: 554-559, 1992.

4. Hart GW. Glycosylation. Curr Opin Cell Biol 4: 10171023, 1992.

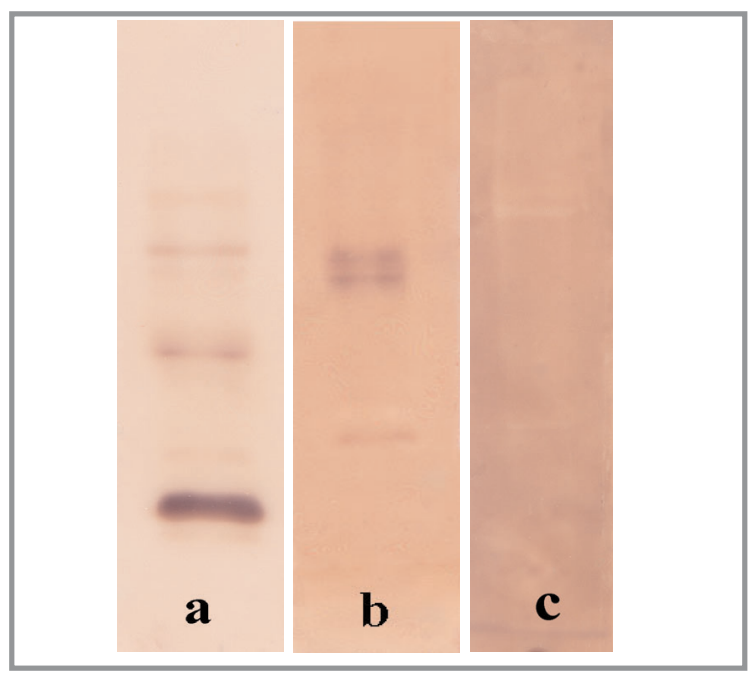

Figure 5. Incubation of erythrocyte membrane extracts from 1 month old rats with lectins pre-incubated with control glycoproteins. (a) MAA-fetuin, (b) SNA-transferrin, (c) PNA-asialofetuin

5. Lis $\mathrm{H}$, Sharon $\mathrm{N}$. Protein glycosylation. Structural and functional aspects. Eur J Biochem 218: 1-27, 1993.

6. Margolis RK, Margolis RU. Nervous tissue proteoglycans. Experientia 49: 429-446, 1993.

7. Hölemann A, Seeberger PH. Carbohydrate diversity: synthesis of glycoconjugates and complex carbohydrates. Curr Opin Biotechnol 15: 615-622, 2004.

8. Varki A. Biological roles of oligosaccharides: all of the theories are correct. Glycobiology 3: 97-130, 1993.

9. Varki A. Sialic acids as ligands in recognition phenomena. FASEB J 11: 248-255, 1997

10. Chihiro S, Ken S. Glycobiology of di- and oligosialyl glycotopes. Trends Glycosci Glycotechnol 11: 371-390, 1999.

11. Varki A, Cummings R, Esko J, et al. Essentials of Glycobiology. Cold Spring Harbor Laboratory Press. 1999.

12. Schauer R. Sialic acids as antigenic determinants of complex carbohydrates. Adv Exp Med Biol 228: 47-72, 1988.

13. Schauer R. Achievements and challenges of sialic acid research. Glycoconj J 17:485-499, 2000.

14. Schauer R. Sialic acids: fascinating sugars in higher animals and man. Zoology 107: 49-64, 2004.

15. Schauer R. Sialic Acids and Their Role as Biological Masks. Trends Biochem Sci 10: 357-360, 1985.

16. Jancik J, Schauer R. Sialic acid a determinant of the life-time of rabbit erythrocytes. Hoppe Seylers Z Physiol Chem 335: 395-401, 1974.

17. Aminoff D, Bell WC, Fulton I, Ingebrightsen N. Effect of sialidase on the viability of erythrocytes in circulation. Am J Haematol 1: 419-432, 1976.

18. Schauer R. Chemistry, metabolism, and biological functions of sialic acids, Adv Carbohydr Chem Biochem 40: 131-234, 1982. 
19. Schauer R, Shukla AK, Schröder C, Muller E. The anti-recognition function of sialic acids: studies with erythrocytes and macrophages. Pure Appl Chem 56: 907-921, 1984.

20. Gavella M, Lipovac V. Erythrocyte sialic acid alterations in experimental diabetes. Cell Mol Biol 31: 75-80, 1985.

21. Greenwalt TJ, Steane EA. Quantitative haemagglutination. 5. Influence of in vivo aging and neuraminidase treatment on the $\mathrm{M}$ and $\mathrm{N}$ antigens of human red cells. Br J Haematol 25: 217-226, 1973.

22. Gattegno L, Bladier D, Gamier M, Carnillot P. Changes in carbohydrate content of surface membranes of human erythrocytes during aging. Carbohydr Res 52: 197-208, 1976.

23. Dodge JT, MitchellC, Hanahan D J. The preparation and chemical characteristics of hemoglobin-free ghosts of human erythrocytes. Arch Biochem Biophys 100: 119-130, 1963.

24. Wang WC, Cummings RD. The immobilized leukoagglutinin from the seeds of Maackia amurensis binds with high affinity to complex-type Asn-linked oligosaccharides containing terminal sialic acid-linked aLpha-2,3 to penultimate galactose residues. J Biol Chem 263: 4576-4585, 1988.

25. Shibuya N, Goldstein IJ, Broekaert WF, et al. The elderberry (Sambucus nigra L.) bark lectin recognizes the Neu5Ac (alpha 2-6) Gal/GalNAc sequence. J Biol Chem 262: 1596-1601, 1987.

26. Goldstein IJ, Hayes CE. The lectins: carbohydrate-binding proteins of plants and animals. Adv Carbohydr Chem Biochem 35: 127-340, 1978.

27. Laemmli UK. Cleavage of structural proteins during the assembly of the head of bacteriophage T4. Nature 227: 680-685, 1970

28. Towbin H, Staehelin T, Gordon J. Electrophoretic transfer of proteins from polyacrylamide gels to nitrocellulose sheets: procedure and some applications. Proc Natl Acad Sci USA 76: 4350-4354, 1979.

29. Gattegno L, Bladier D, Cornillot P. Aging in vivo and neuraminidase treatment of rabbit erythrocytes: influence on half-life as assessed by $51 \mathrm{Cr}$ labelling. Hoppe Seylers Z Physiol Chem 356: 391-397, 1975.

30. Thomas DB, Winzler RJ. Structural studies on human erythrocyte glycoproteins. Alkali-labile oligosaccharides. J Biol Chem 244: 5943-5946, 1969.

31. Krotkiewski H, Lisowska E, Angel AS, Nilsson B. Structural analysis by fast-atom-bombardment mass spectrometry of the mixture of alditols derived from the O-linked oligosaccharides of murine glycophorins. Carbohydr Res 184: 27-38, 1988.

32. Yoshima H, Furthmayr H, Kobata A. Structures of the asparagine-linked sugar chains of glycophorin A. J Biol Chem 255: 9713-9718, 1980.

33. Angel AS, Gronberg G, Krotkiewski H, Lisowska E, Nilsson B. Structural analysis of the N-linked oligosaccharides from murine glycophorin. Arch. Biochem. Biophys 291: 76-88, 1991.
34. Bratosin D, Mazurier J, Debray H, Lecocq M, Boilly B, Alonso C, Moisei M, Motas C, Montreuil J. Flow cytofluorimetric analysis of young and senescent human erythrocytes probed with lectins. Evidence that sialic acids control their life span. Glycoconj J 12: 258-267, 1995.

35. Seaman GVF, Knox RJ, Nordt FJ, Regan DH. Red cell aging, I: surface charge density and sialic acid content of density-fractionated human erythrocytes. Blood 50: 1001-1011, 1977.

36. Hadengue AL, Del-Pino M, Simon A, Levenson J. Erythrocyte disaggregation shear stress, sialic acid, and cell aging in humans. Hypertension 32: 324-330, 1998.

37. Skutelsky E, Marikovsky Y, Cividalli L, Danon D. The relationship between sialic acid content and peanut agglutinin binding on senescent and enzyme treated human erythrocytes. Mech Aging Dev 31: 13-23, 1985.

38. Fairbanks G, Steck TL, Wallach DFH. Electrophoretic analysis of the major polypeptides of the human erythrocyte membrane. Biochemistry 10: 2606-2607, 1971.

39. Tsuji T, Irimura T, Osawa T. The carbohydrate moiety of band 3 glycoprotein of human erythrocyte membranes. Structures of lower molecular weight oligosaccharides. J Biol Chem 256: 10497-10502, 1981.

40. Tsuji T, Irimura T, Osawa T. The carbohydrate moiety of band-3 glycoprotein of human erythrocyte membranes. Biochem J 187: 677-686, 1980.

41. Fukuda M, Dell A, Oates JE, Fukuda MN. Structure of branched lactosaminoglycan, the carbohydrate moiety of band 3 isolated from adult human erythrocytes. J Biol Chem 259: 8260-8273, 1984.

42. Bratosin D, Mazurier J, Tissier JP, et al. Cellular and molecular mechanisms of senescent erythrocyte phagocytosis by macrophages. A review. Biochimie 80: 173-195, 1998.

\section{Yazışma Adresi}

Yrd. Doç. Dr. Erdal BALCAN

Celal Bayar Üniversitesi Fen-Edebiyat Fakültesi

Biyoloji Bölümü, Moleküler Biyoloji Anabilim Dalı

45047 Muradiye Kampüsü

Manisa / TURKEY

Phone: (+90.236) $2412151 / 179$ - 146

Fax: $\quad$ (+90.236) 2362412158

E-posta: erdal.balcan@gmail.com erdal.balcan@bayar.edu.tr 